\title{
Effects of histamine type 2 receptor stimulation on myocardial function in normal subjects
}

\author{
JOHN WATKINS, ^ HENRY J DARGIE,† MORRIS J BROWN, DENNIS M KRIKLER, \\ COLIN T DOLLERY
}

\author{
From the Department of Clinical Pharmacology and Division of Cardiovascular Disease, Royal Postgraduate \\ Medical School, London
}

SUMMARY Myocardial histamine $(\mathrm{H})_{2}$ receptor stimulation has been studied in six normal men. Since histamine is a potent vasodilator, the haemodynamic effects of histamine infusion were compared with those of nitroprusside at equihypotensive doses, to identify changes in myocardial contractility attributable to vasodilatation.

After $\mathrm{H}_{1}$ receptor blockade with mepyramine, subjects received, in single blind crossover fashion, either histamine alone and with the $\mathrm{H}_{2}$ receptor antagonist cimetidine, or nitroprusside alone and with cimetidine. Echocardiographic left ventricular dimensions, plasma catecholamines, blood pressure, and heart rate were measured. The rise in catecholamines suggested similar baroreflex activation by both histamine and nitroprusside. Echo ejection phase indices did not alter significantly after nitroprusside, but histamine caused an increase in percentage fractional shortening from $38 \cdot 2 \pm 4 \cdot 1$ to $53.5 \pm 3-6 \%$ and in mean fibre shortening velocity from $1 \cdot 31 \pm 0 \cdot 19$ to $1 \cdot 99 \pm 0.22 \mathrm{~cm} / \mathrm{s}$. These changes were both greatly reduced by cimetidine and suggest that $\mathrm{H}_{2}$ receptor stimulation in man causes a direct positive inotropic response.

Histamine has multiple sites of action within the cardiovascular system, subserved by two receptor populations, types $\mathrm{H}_{1}$ and $\mathrm{H}_{2} \cdot{ }^{1}$ Human myocardium ${ }^{2}$ and arterial wall ${ }^{3}$ are both thought to contain $\mathrm{H}_{1}$ and $\mathrm{H}_{2}$ receptors. Histamine infusion causes flushing, vasodilatation, and increased cardiac output in man. ${ }^{4}$ It is not clear, however, whether this increase in cardiac output is merely secondary to the fall in systemic vascular resistance and increase in heart rate, or the result of a direct myocardial positive inotropic effect of histamine.

Isolated mammalian heart studies have shown four major effects of histamine $e^{5-7}$ including a positive chronotropic effect, a negative dromotropic effect (decreased atrioventricular conduction), a positive inotropic effect, and increased cardiac automaticity.

The receptor types mediating these effects are species specific $^{5-7}$ but, in several preparations, $\mathrm{H}_{3}$ receptor stimulation gives a positive chronotropic and negative dromotropic effect and an increase in cardiac automaticity. Recent in vitro studies in isolated human

^Present address: John Radcliffe Hospital, Oxford.

†Present address: Western Infirmary, Glasgow G11 6NT.

Accepted for publication 10 December 1981 fetal heart have also shown an $\mathrm{H}_{2}$ receptor mediated positive inotropic response. ${ }^{2} \mathrm{No}^{2}$ in vivo studies in man have previously been performed and, before the availability of cimetidine, human study in vivo was greatly restricted by the absence of a safe $\mathrm{H}_{2}$ receptor antagonist.

It is now known that both $\mathrm{H}_{1}$ and $\mathrm{H}_{2}$ receptors mediate vasodilatation in $\operatorname{man}^{8}$ and, though the widespread use of cimetidine (a specific $\mathrm{H}_{2}$ receptor antagonist) for the treatment of peptic ulceration has been regarded as being without significant cardiovascular risk, isolated case reports of bradycardia, heart block, and hypotension have been reported. ${ }^{9-12}$

No obvious physiological or pathological role for myocardial histamine receptors has emerged, though they may be important in mediating the cardiovascular sequelae in anaphylaxis. ${ }^{13}$

We have, therefore, studied, by non-invasive means, the effects of direct myocardial $\mathrm{H}_{1}$ receptor stimulation in man.

\section{Subjects and methods}

Six male volunteers, weighing $\mathbf{7 4 \cdot 0} 0 \pm \mathbf{4 \cdot 2}( \pm 1 \mathrm{SD}) \mathrm{kg}$ and aged 29 to 34 years, were studied. All were nor- 
motensive, free from cardiovascular disease, and had normal resting electrocardiograms and $M$-mode echocardiograms. (Subjects with a history of atopy, bronchospasm, dyspepsia, or urticaria were specifically excluded.)

Written informed consent was obtained and the procedure was approved by the Research Ethics Committee of the Royal Postgraduate Medical School, London. These studies were performed under basal conditions in a warm, well lit, clinical laboratory. Each subject was studied twice (once with histamine and once with nitroprusside) and the studies were performed at least $\mathbf{4 8}$ hours apart, but at approximately the same time of day. Subjects were fasted for four hours, were all non-smokers, and took no caffeinecontaining beverages or medications of any kind in the week preceding study.

A "19" gauge butterfly needle (Abbott) was inserted into a peripheral arm vein for collection of blood for catecholamine estimation, and was primed with heparinised saline. A 5 in polythene intravenous cannula (Medicath.) was inserted into an antecubital vein on the opposite arm for drug administration by means of a variable delivery rate infusion pump (Braun). Subjects were then instructed to lie in a $50^{\circ}$ left anterior oblique position, which was individually optimised for M-mode echocardiographic recording (Cambridge and Irex Instruments Ltd) of left ventricular cavity dimensions. This position was then unchanged for the remainder of the study. A simultaneous indirect right carotid artery waveform was also recorded, using a pressure sensitive device held against the neck. All recordings were taken during quiet, normal respiration. Heart rate was displayed and the electrocardiogram visualised on a cardiac monitor (Hewlett Packard). Systemic blood pressure was recorded in duplicate from the right arm, using an automatic ultrasonic recorder (Arteriosonde Roche 1217).

Subjects received, single blind, four consecutive 20 minute drug infusions (Fig. 1). Blood pressure and heart rate were recorded every minute and, in addition, plasma catecholamines, echocardiographic left ventricular cavity dimensions, and carotid arterial waveform were recorded, in that order, in the final five minutes of each infusion: (1) saline $0.9 \%$ at $1 \mathrm{ml} /$ minute; (2) mepyramine (a specific $\mathrm{H}_{1}$ receptor antagonist), $0.05 \mathrm{mg} / \mathrm{kg} /$ per min to a mean total dose of $74.0 \mathrm{mg}$; (3) in randomised, crossover fashion, either (a) histamine acid phosphate or (b) sodium nitroprusside.

The infusion rates for the histamine and nitroprusside were adjusted over the first nine minutes to cause a stable fall in diastolic blood pressure of $15 \mathrm{mmHg}$, compared with post-mepyramine values. Histamine infusions were started at $1.0 \mu \mathrm{g} / \mathrm{kg}$ per $\min$ and

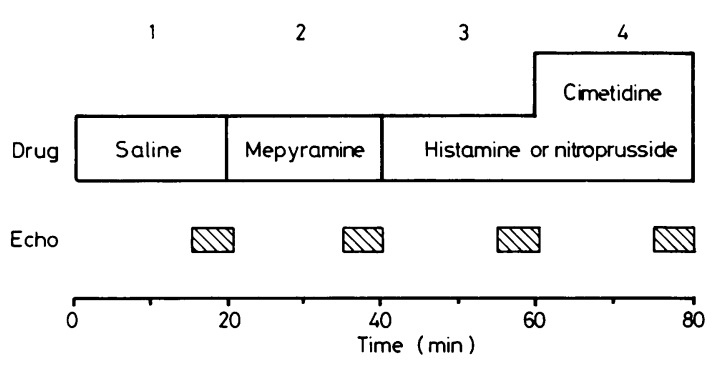

Fig. 1 Study procedure.

increased as necessary every three minutes by $0.25 \mu \mathrm{g} / \mathrm{kg}$ per min (mean rate required $1.5 \pm 0.10 \mu \mathrm{g} / \mathrm{kg}$ per min). Nitroprusside infusions were started at $0.2 \mu \mathrm{g} / \mathrm{kg}$ per min and increased as necessary every three minutes by $0.2 \mu \mathrm{g} / \mathrm{kg}$ per min (mean rate required $0 \cdot 6 \pm 0 \cdot 16 \mu \mathrm{g} / \mathrm{kg}$ per min). Both histamine and nitroprusside infusions were light shielded.

With either histamine or nitroprusside continuing for a further 20 minutes, cimetidine (a specific $\mathrm{H}_{1}$ receptor antagonist) was given in a bolus of $100 \mathrm{mg}$ over three minutes via the butterfly needle, followed by an infusion of $0.2 \mathrm{mg} / \mathrm{kg}$ per min (mean total dose $396 \mathrm{mg}$ ). The initial bolus was given to achieve rapid blood levels of $\geq 1 \mu \mathrm{g} / \mathrm{ml}$, a concentration known to inhibit $\mathrm{H}_{2}$ receptor mediated gastric acid release by at least $50 \% .{ }^{2}$

All blood samples were of $10 \mathrm{ml}$ volume, taken into chilled glass lithium heparin tubes, spun immediately at $4^{\circ} \mathrm{C}$, separated, and the plasma stored at $-20^{\circ} \mathrm{C}$ for assay within two weeks. Plasma noradrenaline and adrenaline were determined by the radioenzymatic catechol-o-methyl transferase method of $\mathrm{Da}$ Prada and Zürcher. ${ }^{15}$ The coefficients of variation within and between assays were 2.9 and $5.3 \%$, respectively, and the sensitivity of the assay for both noradrenaline and adrenaline was $3 \mathrm{pg}$.

All $\mathrm{M}$-mode echocardiographic recordings were performed through the same interspace on each individual and by the same investigator, the transducer placement being marked indelibly on the chest wall at the first study. Standard recordings of the left ventricular cavity just below the mitral valve were obtained over six cardiac cycles, ${ }^{16}$ using a $2.5 \mathrm{MHz}$ unfocused transducer and a paper speed of $5 \mathrm{~cm} / \mathrm{s}$. Left ventricular dimensions were measured between the endocardial surfaces of the posterior wall and the left side of the ventricular septum using the "leading edge" convention. Only subjects in whom septal and posterior wall endocardial echoes could be defined throughout the cardiac cycle were included in the study. The left ventricular end-diastolic dimension (EDD) was measured coincident with the peak of the $\mathrm{R}$ wave of a simultaneously recorded electrocardio- 
gram. The left ventricular end-systolic dimension (ESD) was defined as the smallest distance between septal and posterior wall endocardial surfaces during systole. Left ventricular ejection time (ET) was measured from the initial rapid upstroke of the carotid arterial pulse to the incisura of the dicrotic notch. Fractional shortening (FS) was calculated as (EDDESD)/EDD\%. The mean normalised velocity of left ventricular fibre shortening was calculated as (EDD$\mathrm{ESD}) /(\mathrm{EDD} \times \mathrm{ET})$.

The data of each individual were measured over six cardiac cycles and averaged. All echo recordings were read "blind" by two investigators (JW and HJD) and their measurements were averaged in the event of disparity. Records were measured to the nearest $1 \mathrm{~mm}$. Final data presented were the mean of six subjects \pm 1 standard deviation from the mean.

Statistical analysis was performed by least squares analysis of variance and, where appropriate, by paired " $\mathrm{t}$ " tests.

\section{Results}

Except where otherwise stated, statistical comparisons refer to differences between data derived from parallel steps in the histamine and nitroprusside studies. In Table 1 the effects of histamine and nitroprusside infusions have been compared with the effects of mepyramine to allow identification of a specific $\mathrm{H}_{2}$ effect of the histamine infusion. There was, however, no significant difference in any variable between the saline and mepyramine periods. Three subjects experienced some nausea during the mepyramine infusion with associated pallor and a reduction in heart rate of 79 beats a minute. Diastolic blood pressure also rose 3 to $5 \mathrm{mmHg}$. Thereafter haemodynamic observations were stable.

Histamine, in addition to its haemodynamic effects, caused distinct flushing of the face and trunk, conjunctival suffusion, and mild throbbing headache. All subjects reported an awareness of forceful heartbeat. These effects were all rapidly and totally reversed by cimetidine. Mild facial flushing was observed in two subjects during nitroprusside infusion and this was not reversed by cimetidine.

\section{BLOOD PRESSURE}

A stable fall in diastolic blood pressure of $17 \mathrm{mmHg}$ was achieved with nitroprusside and of $15 \mathrm{mmHg}$ with histamine (Table 1). Systolic blood pressure fell 10 and $3 \mathrm{mmHg}$, respectively. The absolute values of blood pressure after these two drugs were not significantly different. Concurrent administration of cimetidine reversed the hypotension caused by histamine, but not that caused by nitroprusside.

\section{HEART RATE}

Histamine caused a rise in heart rate of 12 beats a minute and nitroprusside of seven beats a minute compared with post-mepyramine heart rates (NS). Cimetidine did not significantly inhibit the tachycardia induced by either vasodilator (Table 1).

\section{CATECHOLAMINES}

Plasma noradrenaline rose from $1 \cdot 24 \pm 0.47$ to $1.77 \pm 0.24 \mathrm{nmol} / 1(0.21 \pm 0.08$ to $0.30 \pm 0.04 \mathrm{ng} / \mathrm{ml})$ during histamine $(p<0.05)$ and from $1.30 \pm 0.35$ to $1.83 \pm 0.41 \mathrm{nmol} / 1(0.22 \pm 0.06$ to $0.31 \pm 0.07 \mathrm{ng} / \mathrm{ml})$ during nitroprusside $(\mathrm{p}<0.05)$.

Plasma adrenaline rose from $0.23 \pm 0.033$ to $0.29 \pm 0.06 \mathrm{nmol} / 1(0.042 \pm 0.006$ to $0.053 \pm 0.012 \mathrm{ng} /$ $\mathrm{ml})$ during histamine $(\mathrm{p}>0.05)$, and from $0.23 \pm 0.033$ to $0.31 \pm 0.06 \mathrm{nmol} / 1(0.042 \pm 0.006$ to $0.056 \pm 0.011$ $\mathrm{ng} / \mathrm{ml}$ ) during nitroprusside $(\mathrm{p}>0.05$ ).

Basal levels of both noradrenaline and adrenaline fell within our laboratory normal range for supine rest. Catecholamine levels at peak histamine and peak nitroprusside infusions were not significantly different.

\section{LEFT VENTRICULAR CAVITY DIMENSIONS}

End-systolic and end-diastolic dimensions are shown in Fig. 2. End-diastolic dimensions were not significantly altered by any drug intervention. During histamine it was $5 \cdot 1 \pm 0.3 \mathrm{~cm}$, and during nitroprusside it was $4.8 \pm 0.3 \mathrm{~cm}(\mathrm{NS})$. There was a tendency in

Table 1 Blood pressure and heart rate changes ( \pm standard deviation) in histamine and nitroprusside studies

\begin{tabular}{|c|c|c|c|c|}
\hline \multirow[t]{2}{*}{ Drug } & \multicolumn{2}{|c|}{ Blood pressure $(\mathrm{mmHg})$} & \multicolumn{2}{|c|}{ Heart rate (beats/min) } \\
\hline & $\begin{array}{l}\text { Histamine } \\
\text { study }\end{array}$ & $\begin{array}{l}\text { Nitroprusside } \\
\text { study }\end{array}$ & $\begin{array}{l}\text { Histamine } \\
\text { study }\end{array}$ & $\begin{array}{l}\text { Nitroprusside } \\
\text { study }\end{array}$ \\
\hline $\begin{array}{l}\text { Saline } \\
\text { Mepyramine } \\
\text { H/NP infusion } \\
\text { H/NP infusion + cimetidine }\end{array}$ & $\begin{array}{l}116 / 73 \pm 10 / 9 \\
117 / 76 \pm 9 / 7 \\
114 / 61^{\star} \pm 11 / 6 \\
118 / 75 \pm \pm 11 / 8\end{array}$ & $\begin{array}{l}116 / 73 \pm 11 / 3 \\
120 / 80 \pm 9 / 6 \\
110 / 63 \dagger \pm 9 / 3 \\
114 / 66 \pm 8 / 8\end{array}$ & $\begin{array}{l}75 \pm 10 \\
68 \pm 6 \\
80 \pm 14 \\
76 \pm 9\end{array}$ & $\begin{array}{l}73 \pm 9 \\
68 \pm 11 \\
75 \pm 7 \\
75 \pm 8\end{array}$ \\
\hline
\end{tabular}

$\mathrm{H}$, histamine; NP, nitroprusside; ${ }^{\star} \mathrm{p}<0.05$ compared to mepyramine; $\nmid \mathrm{p}<0.01$ compared to mepyramine; $\neq \mathrm{p}<0.05$ compared to histamine. Note: Nitroprusside caused a fall in diastolic blood pressure of $17 \mathrm{mmHg}$ and histamine of $15 \mathrm{mmHg}$ compared with mepyramine, but absolute values of blood pressure during histamine and nitroprusside infusions were not significantly different. 


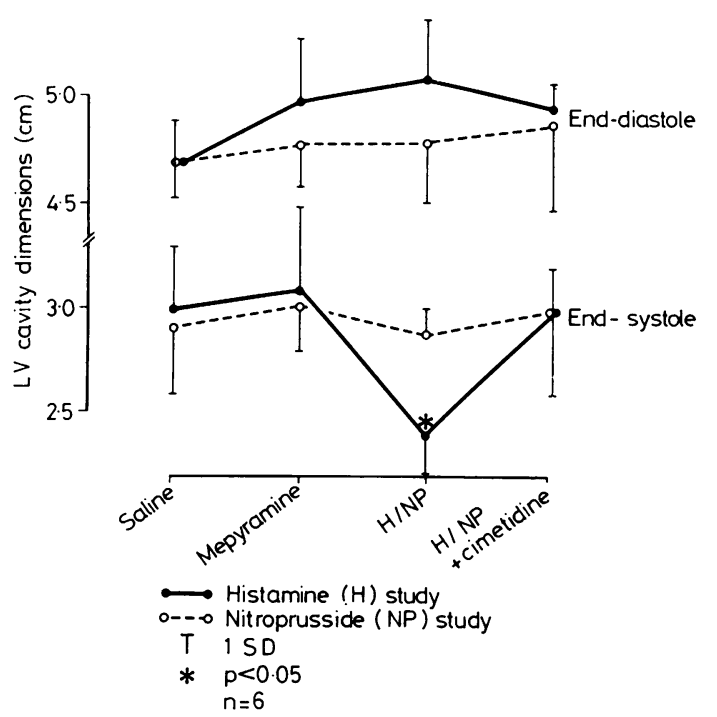

Fig. 2 Effect of histamine and nitroprusside on left ventricular short axis cavity dimensions.

both studies for the end-diastolic dimension to increase as a function of time.

End-systolic dimension, however, was reduced from $3 \cdot 1 \pm 0.4 \mathrm{~cm}$ after mepyramine to $2 \cdot 4 \pm 0.2 \mathrm{~cm}$ during histamine $(p<0.05)$. During the nitroprusside infusion no comparable fall in end-systolic dimension

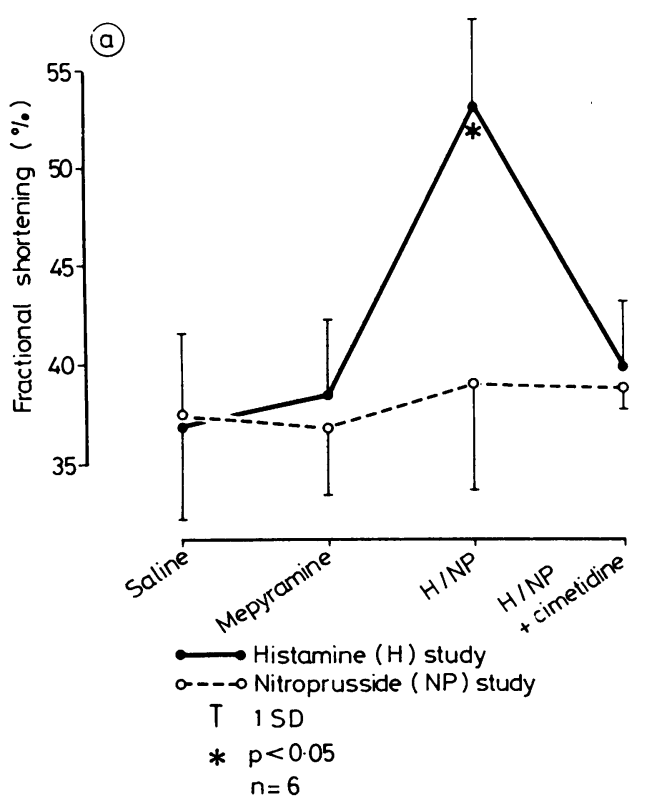

was seen at an equihypotensive dose, the dimension remaining unchanged at $2.9 \pm 0.1 \mathrm{~cm}(\mathrm{p}<0.05 \mathrm{com}-$ pared with end-systolic dimension during histamine).

In the histamine study, end-systolic dimension returned to $3.0 \pm 0.2 \mathrm{~cm}$ after concomitant administration of cimetidine $(p<0.05$ compared with endsystolic dimension during histamine alone).

\section{ECHO EJECTION PHASE INDICES}

\section{(a) Fractional shortening}

Histamine infusion caused a pronounced increase in fractional shortening compared with nitroprusside at equihypotensive doses (see Fig. 3a). At peak histamine infusion, fractional shortening was $53.5 \pm 3.6 \%$ whereas at peak nitroprusside infusion it was only $39.2 \pm 5.4 \%(p<0.05)$. Cimetidine administration during the histamine infusion caused a reduction in fractional shortening to $40.3 \pm 3.1 \%(p<0.05$ compared with fractional shortening during histamine alone) but no significant change when added during the nitroprusside infusion.

\section{(b) Fibre shortening velocity}

Fibre shortening velocity increased from $1 \cdot 31 \pm 0 \cdot 19$ to $1.99 \pm 0.22 \mathrm{~cm} / \mathrm{s}$ during histamine $(\mathrm{p}<0.05)$-see Fig. 3b. Nitroprusside caused a smaller rise, from $1.23 \pm 0.11$ to $1.49 \pm 0.22 \mathrm{~cm} / \mathrm{s}(p<0.05)$. Both absolute and indexed values at peak histamine, however, were significantly greater than those during nitro-

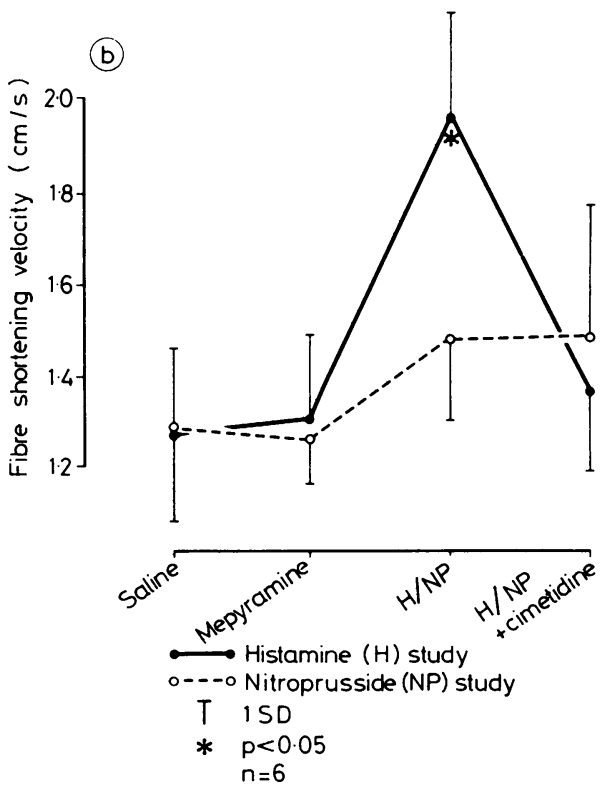

Fig. 3 Effect of histamine and nitroprusside on echocardiographic ejection phase indices of left ventricular performance. (a) \% fractional shortening, (b) fibre shortening rate. 
Table 2 Left ventricular ejection times (observed and indexed) during histamine and nitroprusside studies

\begin{tabular}{|c|c|c|c|c|}
\hline \multirow[t]{2}{*}{ Drug } & \multicolumn{2}{|c|}{ Observed LVET (ms) } & \multicolumn{2}{|c|}{$\begin{array}{l}\text { Indexed LVET (ms) } \\
\text { (observed LVET+I.7×HR) }\end{array}$} \\
\hline & $\begin{array}{l}\text { Histamine } \\
\text { study }\end{array}$ & $\begin{array}{l}\text { Nitroprusside } \\
\text { study }\end{array}$ & $\begin{array}{l}\text { Histamine } \\
\text { study }\end{array}$ & $\begin{array}{l}\text { Nitroprusside } \\
\text { study }\end{array}$ \\
\hline $\begin{array}{l}\text { Saline } \\
\text { Mepyramine } \\
\text { H/NP infusion } \\
\text { H/NP infusion + cimetidine }\end{array}$ & $\begin{array}{l}288 \pm 16 \\
292 \pm 16 \\
269 \pm 30^{\star} \\
292 \pm 24 十^{\star}\end{array}$ & $\begin{array}{l}286 \pm 16 \\
299 \pm 8 \\
263 \pm 24^{\star} \\
260 \pm 14\end{array}$ & $\begin{array}{l}416 \pm 4 \\
407 \pm 6 \\
405 \pm 12 \\
423 \pm 6 t^{\star}\end{array}$ & $\begin{array}{l}410 \pm 14 \\
416 \pm 6 \\
391 \pm 20^{\star} \\
390 \pm 18\end{array}$ \\
\hline
\end{tabular}

H, histamine; NP, nitroprusside; LVET, left ventricular ejection time.

Note: There were no significant differences between LVET during the $\mathrm{H}$ and NP infusions. Note, however, that both $\mathrm{H}$ and NP infusions caused LVET to shorten compared with LVET after mepyramine $\left({ }^{\star} \mathrm{p}<0.05\right)$, but that cimetidine reversed only that shortening in LVET caused by histamine $\left(t^{\star} p<0.05\right)$.

prusside infusion (all $\mathbf{p}<0.05$ ). Cimetidine reversed the histamine-induced increase in fibre shortening velocity, but had no effect when given with nitroprusside.

\section{LEFT VENTRICULAR EJECTION TIME}

Absolute and indexed ejection times are shown in Table 2. Both histamine and nitroprusside caused left ventricular ejection time to shorten compared with ejection times after mepyramine, but cimetidine reversed only the shortening in ejection time caused by histamine $(p<0.05$ compared with the ejection time during histamine alone).

\section{Discussion}

This study has confirmed the presence of myocardial $\mathrm{H}_{2}$ receptors in normal subjects, and shown that stimulation of these receptors gives a positive inotropic response. The study was designed in such a way that changes in myocardial contractility directly and reflexly attributable to vasodilatation could be identified. This was achieved by comparing the haemodynamic effects of histamine with those of nitroprusside. Both are potent, short acting vasodilators, but nitroprusside is known to have no direct myocardial effects. ${ }^{17}$ By infusing the same subjects with both drugs at concentrations which gave a similar fall in diastolic blood pressure, we assumed that comparable decreases in peripheral vascular resistance had been achieved. By measuring plasma noradrenaline, an index of sympathetic function, ${ }^{18} 19$ baroreflex activation caused by both vasodilators was also compared. The similar rise in plasma noradrenaline during histamine and nitroprusside infusions suggested an equivalent degree of baroreflex activation in both studies. Though histamine and nitroprusside are both vasodilators, ${ }^{1720}$ their relative potencies are unknown. Left ventricular end-diastolic dimension, however, which reflects preload, ${ }^{21}$ was not significantly altered by either drug, so we feel it was unlikely that the improvements in left ventricular per- formance during histamine $\mathrm{H}_{2}$ receptor stimulation could be solely ascribed to differences in their venodilator properties. Plasma adrenaline was measured, since the positive inotropic effect of histamine might have been mediated by release of catecholamines from the adrenal medulla. In the presence of mepyramine, an $\mathrm{H}_{1}$ receptor antagonist, however, plasma adrenaline levels were similar and not significantly raised during either histamine or nitroprusside infusion. Therefore, if histamine does liberate adrenal medullary catecholamines directly, the response is $\mathrm{H}_{1}$ receptor mediated in man and does not contribute to the positive inotropic effect of histamine $\mathrm{H}_{2}$ receptor stimulation seen in this study.

Thus, an improvement in left ventricular performance was observed during histamine $\mathrm{H}_{2}$ receptor stimulation, which appeared not to have been attributable to the direct or reflex effects of vasodilatation. Moreover, this effect was almost completely reversed by concomitant administration of cimetidine, an $\mathrm{H}_{2}$ receptor antagonist which in the regimen used in this study has no apparent intrinsic haemodynamic effects. ${ }^{14}$ (Unpublished studies from our own laboratory have also failed to show any haemodynamic effects following acute intravenous administration of cimetidine in normal subjects.)

There was no increase in atrioventricular conduction during histamine infusion in the presence of mepyramine, nor any evidence of bronchospasm, suggesting that significant $\mathrm{H}_{1}$ blockade had been achieved. There was, however, a small increase in heart rate but, since this was of the same order of magnitude as that observed during the nitroprusside infusion, we feel that it was likely to be a reflex change secondary to vasodilatation and not due to $\mathrm{H}_{1}$ receptor stimulation. The incomplete reversal by cimetidine of the increase in heart rate during histamine infusion by cimetidine gives rise to the alternative possibility that it was, at least partially, $\mathrm{H}_{2}$ receptor mediated.

Histamine has other cardiovascular effects that were not measured or controlled in this study, that is 
effects on coronary vascular resistance, respiratory influences, direct cerebral effects on the vasomotor centre, and changes in vascular permeability. ${ }^{22}$ While these changes may have accounted for some of the increase in myocardial contractility seen, it is unlikely that their contribution was great. Though cimetidine may cross the blood-brain barrier in man after chronic dosing, ${ }^{23}$ the reversal of the positive inotropic effect was very rapid after cimetidine administration. A centrally mediated effect, therefore, seems less likely, but cannot be ruled out. The effects of vascular permeability could not be quantified and there are no human data. Animal studies, however, suggest that these permeability effects are predominantly $\mathrm{H}_{1}$ receptor mediated and therefore not contributory to the changes seen in this study. ${ }^{24}$

The echocardiographic ejection phase indices used have been shown to correlate well with measures of myocardial contractility determined angiographically. ${ }^{25}$ Since serial measurements of left ventricular cavity dimensions in the same subject at rest can vary, even under ideal conditions, by $\pm 3.5 \mathrm{~mm}$ (approximately $10 \%$ of the end-systolic dimension), ${ }^{26}$ dimension changes need to be considerably larger than this before they can be confidently ascribed to a drug effect. ${ }^{27}$ In this study, histamine caused a reduction of end-systolic dimension of $7 \mathrm{~mm}(-22 \%)$.

This was an acute study and there was no measure of the duration of the positive inotropic response. Histamine analogues with specific $\mathrm{H}_{2}$ receptor agonist properties $^{28} 29$ have recently been developed which may enable chronic studies on myocardial $\mathrm{H}_{2}$ receptor stimulation to be made. It will be important to determine whether specific $\mathrm{H}_{2}$ receptor agonists cause a sustained positive inotropic effect and reduction of peripheral vascular resistance in man without undue tachycardia or other unwanted systemic effects: the therapeutic implications of this remain speculative but could include inotropic support in heart failure.

We thank the manufacturers for the loan of Cambridge and Irex echocardiographic equipment for this study.

\section{References}

1 Parsons ME, Owen DAA. Receptors involved in the cardiovascular responses to histamine. International symposium on histamine $\mathrm{H}_{2}$ receptor antagonists. London: Smith Kline and French Labs, 1973: 127-35.

2 Wollemann M, Papp J. Blockade by cimetidine of the effects of histamine on adenylate cyclase activity, spontaneous rate and contractility of the developing praenatal heart. Agents Actions 1979; 9: 29-30.

3 Glover WE, Carroll PR, Latt N. Histamine receptors in the human temporal and rabbit ear arteries. International symposium on histamine $H_{2}$ receptor antagonists. London: Smith Kline and French Labs, 1973: 169-74.

4 Bevan JA, ed. Essentials of pharmacology. Hagerstown, Maryland: Harper \& Row, 1976: 38.

5 Levi R, Capurro N, Lee CH. Pharmacological characterization of cardiac histamine receptors: sensitivity to $\mathrm{H}_{1}$ and $\mathrm{H}_{2}$ receptor agonists and antagonists. Eur $\mathcal{F}$ Pharmacol 1975; 30: 328-35.

6 Woods JR Jr, Brinkman CR, Dandavino A, Murayama $\mathrm{K}$, Assali NS. Action of histamine and $\mathrm{H}_{1}$ and $\mathrm{H}_{2}$ blockers on the cardiopulmonary circulation. Am $\mathcal{f}$ Physiol 1977; 232: H73-8.

7 Levi R, Allan G, Zavecz JH. Cardiac histamine receptors. Fed Proc 1976; 35: 1942-7.

8 Goodman LS, Gilman AG. The pharmacological basis of therapeutics. 5th ed. New York: McMillan, 1975: 591-3.

9 Jefferys DB, Vale JA. Cimetidine and bradycardia (letter). Lancet 1978; i: 828.

10 Reding P, Devroede C, Barbier P. Bradycardia after cimetidine (letter). Lancet 1977; ii: 1227.

11 Mahon WA, Kolton M. Hypotension after intravenous cimetidine (letter). Lancet 1978: i: 828.

12 Ligumsky $M$, Schochina $M$, Rachmilewitz D. Cimetidine and arrhythmia suppression (letter). Ann Intern Med 1978; 89: 1008-9.

13 Eyre $\mathrm{P}$, Wells $\mathrm{PW}$. Histamine $\mathrm{H}_{2}$-receptors modulate systemic anaphylaxis: a dual cardiovascular action of histamine in calves Br $\mathcal{F}$ Pharmacol 1973; 49: 364-7.

14 Burland WL, Duncan WAM, Hesselbo T, et al. Pharmacological evaluation of cimetidine, a new histamine $\mathrm{H}_{2}$ receptor antagonist, in healthy man. Br $\mathcal{F}$ Clin Pharmacol 1975; 2: 481-6.

15 Da Prada M, Zürcher G. Simultaneous radioenzymatic determination of plasma and tissue adrenaline, noradrenaline and dopamine within the fentomole range. Life Sci 1976; 19: 1161-74.

16 Popp RL, Filly K, Brown OR, Harrison DC. Effect of transducer placement on echocardiographic measurement of left ventricular dimensions. Am $\mathcal{f}$ Cardiol 1975; 35: 537-40.

17 Koch-Weser J. Vasodilator drugs in the treatment of hypertension. Arch Intern Med 1974; 133: 1017-27.

18 Yamaguchi N, de Champlain J, Nadeau R. Correlation between the response of the heart to sympathetic stimulation and the release of endogenous catecholamines into the coronary sinus of the dog. Circ Res 1975; 36: 662-8.

19 Watkins J, Fitzgerald G, Zamboulis C, Brown MJ, Dollery CT. Absence of evidence for opiate or histamine $\mathrm{H}_{2}$ receptor mediated effects of clonidine in man. Clin Pharmacol Ther 1980; 28: 605-10.

20 Sharpey-Schafer EP, Ginsburg J. Humoral agents and venous tone: effects of catecholamines, 5 hydroxytryptamine, histamine and nitrites. Lancet 1962; ii: 1337-40.

21 Stefadouros MA, Shahawy ME, Stefadouros F, Witham AC. The effect of upright tilt on the volume of the failing human left ventricle. Am Heart $\mathcal{F}$ 1975; 90: 735-43.

22 Owen DAA. Histamine receptors in the cardiovascular system. Gen Pharmacol 1977; 8: 141-56.

23 Schentag JJ, Cerra FB, Calleri G, DeGlopper E, Rose JQ, Bernhard H. Pharmacokinetic and clinical studies in patients with cimetidine-associated mental confusion. Lancet 1979; i: 177-81. 
24 Church MK, Miller P. Simple models of anaphylaxis and of histamine and 5 Hydroxytryptamine-induced inflammation using the mouse pinna (abstract). $\mathrm{Br} \mathcal{F}$ Pharmacol 1975; 55: 315P.

25 Cooper RH, O'Rourke RA, Karliner JS, Peterson KL, Leopold GR. Comparison of ultrasound and cineangiographic measurements of the mean rate of circumferential fiber shortening in man. Circulation 1972; 46: 914 23.

26 Stefadouros MA, Canedo MI. Reproducibility of echocardiographic estimates of left ventricular dimensions. Br Heart $\mathcal{F}$ 1977; 39: 390-8.

27 Gibson DG. Use of " $M$ " mode echocardiography in clinical pharmacology. Br $\mathcal{F}$ Clin Pharmacol 1979; 7: 443-9.

28 Black JW, Duncan WAM, Durant CJ, Ganellin CR, Parsons EM. Definition and antagonism of histamine $\mathrm{H}_{2}$ receptors. Nature 1972; 236: 385-90.

29 Parsons ME, Owen DAA, Durant GJ, Ganellin CR, et al. Dimaprit -(S-[3-(N,N-dimethylamino) prophyl] isothiourea)-a highly specific histamine $\mathrm{H}_{2}$ receptor agonist. Part I. Pharmacology. Agents Actions 1977; 7: 31-7.

Requests for reprints to Dr Henry J Dargie, Western Infirmary, Glasgow G11 6NT. 